Gut, 1984, 25, 1203-1210

\title{
Surface morphology of the gastroduodenal mucosa in duodenal ulceration
}

\author{
H W STEER \\ From the Southampton General Hospital, Southampton
}

SUMmARY Endoscopic biopsies from the duodenal cap and prepyloric areas of 25 patients have been examined with the scanning electron microscope. Eleven patients had duodenal ulceration. Bacteria are related only to the surface of gastric type epithelial cells whether these cells are located at areas of gastric metaplasia in the duodenal bulb or in the pre-pyloric region of the stomach. The bacteria are not associated with the surface of intestinal type epithelial cells. The bacteria are absent from the biopsies of those patients with a normal stomach and duodenum. Of those patients with duodenal ulceration, $73 \%$ have bacteria related to the epithelial surface. The bacteria are of two morphological types - a kidney shaped bacillus and an S-shaped bacillus.

The simultaneous occurrence of bacteria in the stomach and peptic ulceration has been documented on numerous occasions ${ }^{1-4}$ although there is great range in the frequency of this association and the variety of bacteria. More recent studies have included a qualitative and quantitative morphological approach in order to determine more information about the role, if any, of bacteria in peptic ulceration. ${ }^{56}$ These latter morphological studies have utilised light microscopy and transmission electron microscopy. The distribution of these bacteria correlate with the distribution of gastritis and are related to the area of ulceration. There are significant decreases in the number of mucosal related bacteria after treatment and healing of the ulcers. ${ }^{56}$

If bacteria are implicated in the aetiology of peptic ulceration it is logical to obtain the maximum amount of information about their relationship to the epithelium. The present study involves a scanning electron microscopic examination of the bacterial epithelial relationship in patients with duodenal ulceration and compares the appearances with those found at the normal gastroduodenal mucosa.

\section{Methods}

PATIENTS

Multiple biopsies from 25 patients having an upper

Address for correspondence: Mr H W Steer, FRCS, Southampton General Hospital, Shirley, Southampton SO9 4XY.

Received for publication 9 May 1983 gastrointestinal endoscopy for upper abdominal pain were taken from the prepyloric area of the stomach and the edge of the duodenal ulcers (specimens collected 5 February 1982-29 September 1982). The biopsies were taken from the superior aspect of the gastric mucoa in the immediate prepyloric area and from that edge of the duodenal ulcer nearest the stomach. Details of these patients, the endoscopic findings, biopsy sites and histology are given in Tables 1 and 2 .

The 13 control patients were being investigated for upper abdominal pain and had a normal barium meal as well as a normal endoscopy. The pain in these control patients was transient and has remained undiagnosed. No attempt has been made to match the control patients with those having duodenal ulceration. The control patients were younger with an equal sex distribution.

The biopsies for scanning electron microscopic study were fixed in cacodylate buffered $5 \%$ glutaraldehyde ( $\mathrm{pH} \mathrm{7.3)}$ for 16 hours at $4^{\circ} \mathrm{C}$ and stored for one to five days in cacodylate/sucrose buffer at $4^{\circ} \mathrm{C}$. The specimens were postfixed in $2 \%$ osmium tetroxide and dehydrated in a graded series of acetone. They were critical point dried from acetone in a Polaron E3000 system using liquid carbon dioxide as exchange medium. After mounting onto stubs by means of quick drying silver paint, the specimens were coated with goldpaladium to a thickness of approximately $25 \mathrm{~nm}$ in a Polaron E5100 sputter coater and examined in a JEOL JSM-35 scanning electron microscope (SEM) at $25 \mathrm{KV}$. 
Table 1 Details of the normal patients

\begin{tabular}{|c|c|c|c|c|}
\hline Patient number & Age (yr) & Sex & Endoscopic findings & Biopsy sites (no examined with SEM) \\
\hline 1 & 33 & Female & Normal & Prepyloric area $(\times 2)$ \\
\hline 2 & 48 & Male & Normal & $\begin{array}{l}\text { Duodenal cap }(\times 3) \\
\text { Prepyloric area }(\times 4)\end{array}$ \\
\hline 3 & 28 & Male & Normal & Prepyloric area $(\times 4)$ \\
\hline 4 & 33 & Female & Normal & $\begin{array}{l}\text { Duodenal cap }(\times 4) \\
\text { Prepyloric area }(\times 2)\end{array}$ \\
\hline 5 & 52 & Female & Normal & $\begin{array}{l}\text { Duodenal cap }(\times 2) \\
\text { Prepyloric area }(\times 3)\end{array}$ \\
\hline 6 & 65 & Male & Normal & $\begin{array}{l}\text { Duodenal cap }(\times 1) \\
\text { Prepyloric area }(\times 2)\end{array}$ \\
\hline 7 & 72 & Female & Normal & $\begin{array}{l}\text { Duodenal cap }(\times 1) \\
\text { Prepyloric area }(\times 2)\end{array}$ \\
\hline 8 & 35 & Female & Normal & $\begin{array}{l}\text { Duodenal cap }(\times 1) \\
\text { Prepyloric area }(\times 2)\end{array}$ \\
\hline 9 & 48 & Female & Normal & $\begin{array}{l}\text { Duodenal cap }(\times 1) \\
\text { Prepyloric area }(\times 2)\end{array}$ \\
\hline 10 & 48 & Male & Normal & $\begin{array}{l}\text { Duodenal cap }(\times 1) \\
\text { Prepyloric area }(\times 2)\end{array}$ \\
\hline 11 & 56 & Male & Normal & $\begin{array}{l}\text { Duodenal cap }(\times 1) \\
\text { Prepyloric area }(\times 2)\end{array}$ \\
\hline 12 & 25 & Male & Normal & $\begin{array}{l}\text { Duodenal cap }(\times 1) \\
\text { Prepyloric area }(\times 2)\end{array}$ \\
\hline 13 & 35 & Male & Normal & $\begin{array}{l}\text { Duodenal cap }(\times 2) \\
\text { Prepyloric area }(\times 3)\end{array}$ \\
\hline
\end{tabular}

The material used for light microscopy was also immediately fixed in 5\% cacodylate buffered glutaraldehyde $\left(\mathrm{pH} \mathrm{7.3)}\right.$ for four to 24 hours at $4^{\circ} \mathrm{C}$ and then rinsed in cacodylate buffered $10 \%$ sucrose $(\mathrm{pH}$ $7 \cdot 3$ ) for 24 hours at $4^{\circ} \mathrm{C}$. Post-fixation was carried out in veronal acetate buffered $1 \%$ osmium tetroxide ( $\mathrm{pH} \mathrm{7.3)} \mathrm{for} \mathrm{two} \mathrm{hours} \mathrm{at} 4^{\circ} \mathrm{C}$ after which the specimens were rinsed in chilled tap water $\left(4^{\circ} \mathrm{C}\right)$, dehydrated in a graded series of ethyl alcohol solutions, cleaned in propylene oxide and embedded in Araldite.

Sections $1 \mu \mathrm{m}$ thick were cut with a glass knife on an ultramicrotome and stained. ${ }^{7}$

\section{Results}

NORMAL MUCOSA

Large areas of the prepyloric mucosa are covered

Table 2 Details of the duodenal ulcer patients and the patient with only prepyloric gastritis

\begin{tabular}{|c|c|c|c|c|}
\hline Patient number & Age (yr) & $\operatorname{Sex}$ & Endoscopic findings & Biopsy sites (no examined with SEM) \\
\hline 14 & 49 & Female & Duodenal ulcer & $\begin{array}{l}\text { Duodenal cap }(\times 2) \\
\text { Prepyloric area }(\times 1)\end{array}$ \\
\hline 15 & 84 & Female & Duodenal ulcer & $\begin{array}{l}\text { Duodenal cap }(\times 4) \\
\text { Prepyloric area }(\times 7)\end{array}$ \\
\hline 16 & 24 & Male & Duodenal ulcer & Duodenal cap $(\times 4)$ \\
\hline 17 & 28 & Male & Duodenal ulcer & Prepyloric area $(\times 3)$ \\
\hline 18 & 43 & Female & Duodenal ulcer & Prepyloric area $(\times 2)$ \\
\hline 19 & 52 & Male & Duodenal ulcer and gastritis high on lesser curve & $\begin{array}{l}\text { Duodenal cap }(\times 3) \\
\text { Prepyloric area }(\times 3)\end{array}$ \\
\hline 20 & 57 & Female & Duodenal ulcer-healing & Duodenal cap $(\times 3)$ \\
\hline 21 & 76 & Male & Duodenal ulcer and lesser curve gastric ulcer & $\begin{array}{l}\text { Duodenal cap }(\times 4) \\
\text { Prepyloric area }(\times 3)\end{array}$ \\
\hline 22 & 48 & Male & Duodenal ulcer & Prepyloric area $(\times 4)$ \\
\hline 23 & 49 & Male & Duodenal ulcer & $\begin{array}{l}\text { Duodenal cap }(\times 2) \\
\text { Prepyloric area }(\times 3)\end{array}$ \\
\hline 24 & 41 & Male & Duodenal ulcer & $\begin{array}{l}\text { Duodenal cap }(\times 4) \\
\text { Prepyloric area }(\times 3)\end{array}$ \\
\hline 25 & 44 & Female & Prepyloric gastritis & Prepyloric area $(\times 4)$ \\
\hline
\end{tabular}


with mucus (Fig. 1). Indeed, the prepyloric biopsies from four of the 13 normal patients are completely covered with mucus so that the epithelial surface could not be examined directly in these biopsies. The epithelial cell surface is readily examined at areas lacking mucus. The cells have a dome-shaped surface (Fig. 2). They are related to five or six adjacent cells and the abutting edges are straight. Each cell surface is therefore five or six sided but the sides are not of equal length. There are no gaps between adjacent cells. The centre of the dome shaped surface of an individual cell has fewer microvilli (Fig. 2). The nearer to the edge of each cell surface the greater the number of microvilli present. In fact, in the 'gutters' at the edge of the cells the density of microvilli is so great that they present a 'carpet' of microvilli although they are not intimately apposed to each other in the manner found on the surface of the small intestinal epithelium. There are no bacteria related to the surface of the epithelial cells in the normal biopsies (Table 3).
Table 3 Histology and scanning electron microscope findings in biopsies from the normal patients

\begin{tabular}{lll}
\hline $\begin{array}{l}\text { Patient } \\
\text { number }\end{array}$ & Histology & Scanning electron microscope findings \\
\hline 1 & Normal & $\begin{array}{l}\text { No bacteria } \\
\text { Epithelial surface covered with } \\
\text { mucus }\end{array}$ \\
3 & Normal & No bacteria \\
4 & Normal & No bacteria \\
5 & Normal & No bacteria \\
6 & Normal & No bacteria \\
7 & Normal & No bacteria \\
8 & Normal & No bacteria \\
9 & Normal & Epithelial surface covered with \\
& Normal & mucus \\
10 & Normal & Epithelial surface covered with \\
& mucus \\
11 & Normal & No bacteria \\
12 & Normal & Epithelial surface covered with \\
& & mucus \\
13 & Normal & No bacteria \\
\hline
\end{tabular}

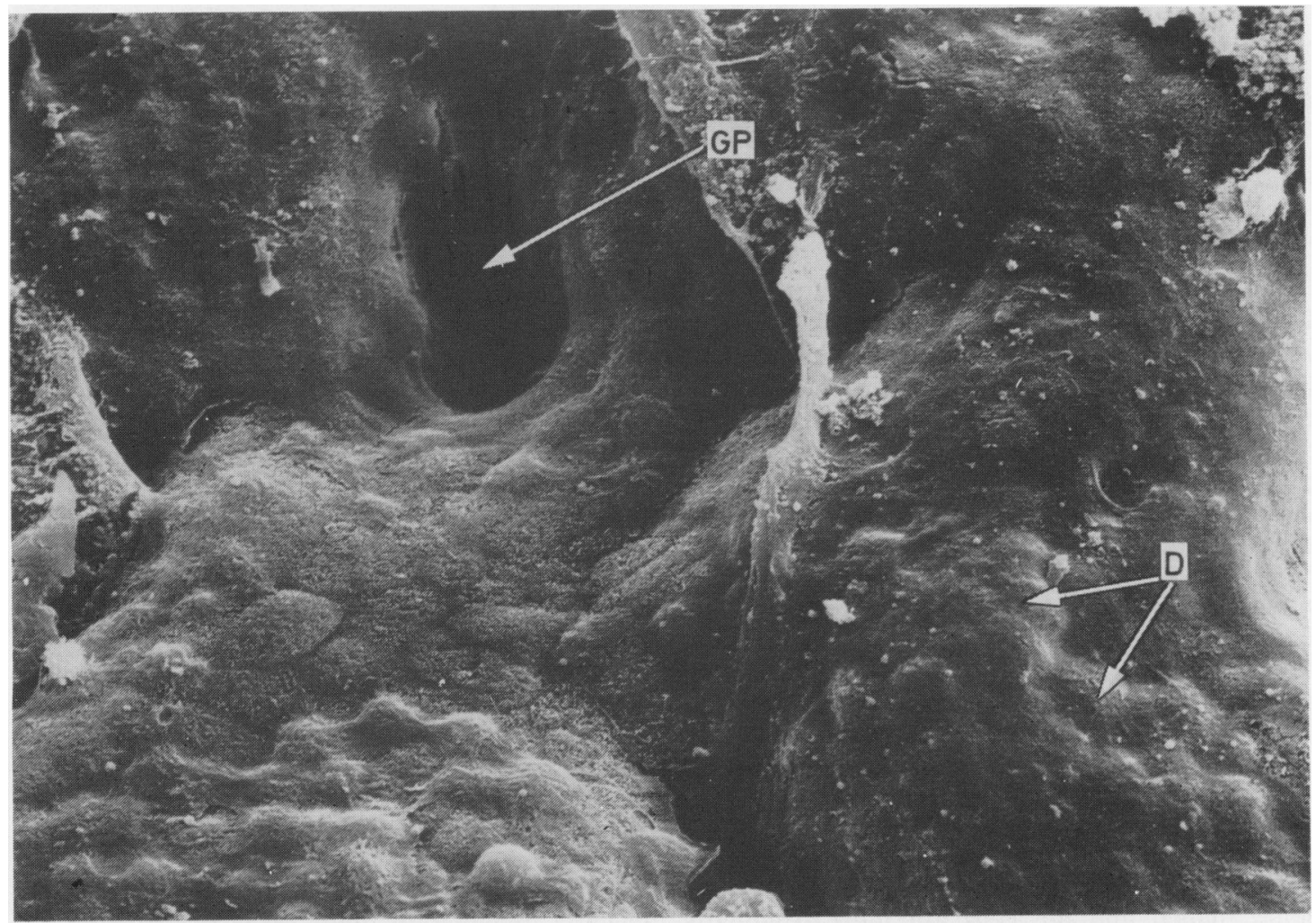

Fig. 1 Surface epithelium of the prepyloric gastric mucosa covered with a thin layer of mucus. Domes of individual epithelial cells can be seen $(D)$. A gastric pit $(G P)$ is present $(\times 1250$ original magnification). 


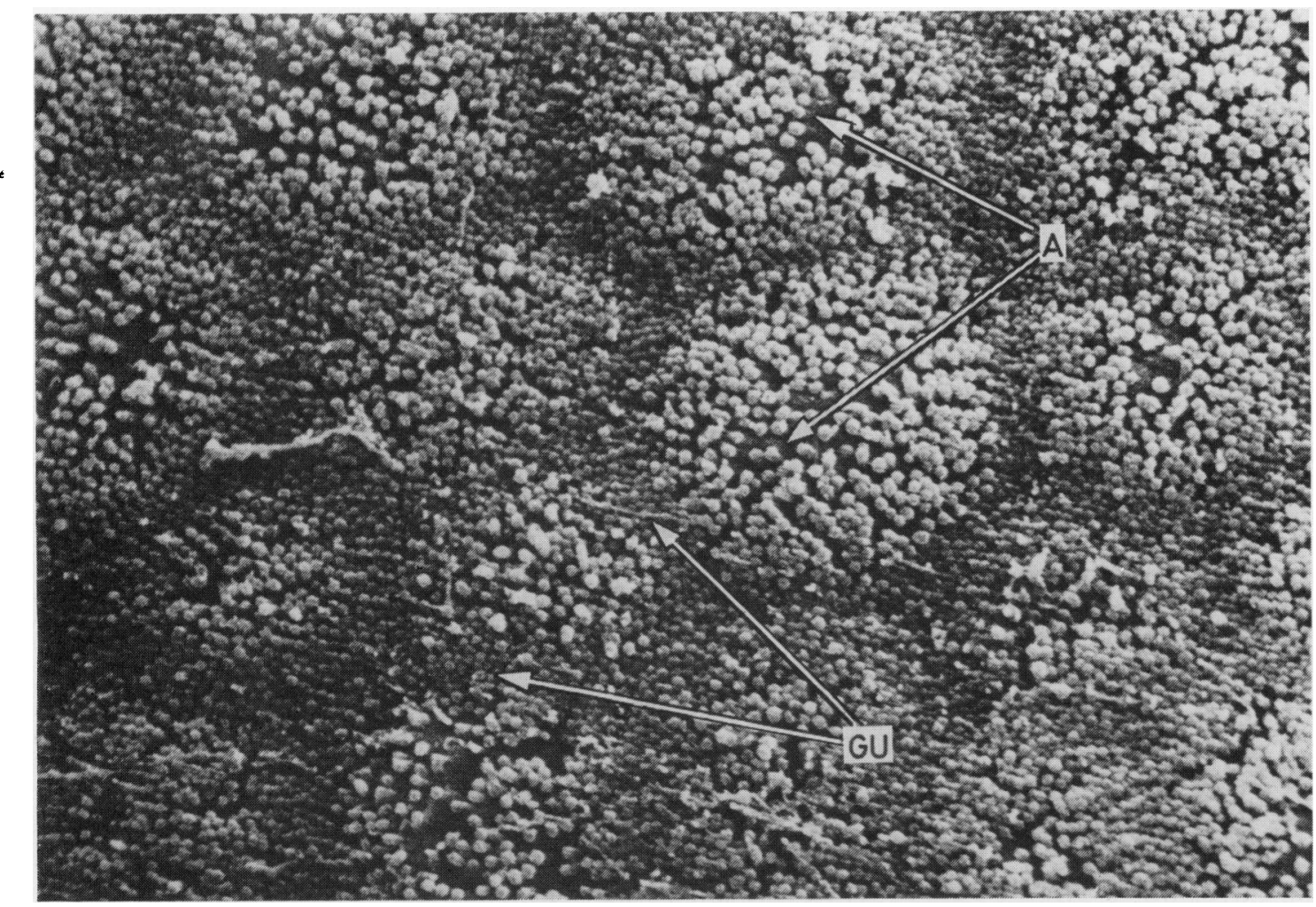

Fig. 2 Detailed study of the dome shaped surface of normal gastric epithelial cells showing the densely packed microvilli in the gutters $(G U)$ at the edges of the cells and the less dense microvilli at the apex of the cell surface $(A)(\times 8400$ original magnification).

MUCOSA IN DUODENAL ULCER PATIENTS

A major portion of the epithelial surface of some biopsies from patients with duodenal ulceration is covered with mucus preventing a detailed study of the cell surface (Fig. 3 ). The adherent mucus is complete in only one patient in this group so that the surface epithelium could be examined in 10 of the 11 patients with duodenal ulceration. The mucus on the biopsy surface is irregularly disturbed. Frequently, white and red blood cells are related to the mucus. Bacteria are rarely found on the luminal surface of the mucus but has been shown to be related to the epithelial surface of the mucus when examined with the transmission electron microscope. ${ }^{6}$

The epithelial cell surface from patients with duodenal ulceration is formed of either gastric epithelial cells or intestinal type cells. The gastric epithelial cells resemble those present in control biopsies except for the facts that the surface is more dome shaped and the cells are more irregularly arranged with occasional gaps between the cells. White blood cells are related to these gaps and to the epithelial cell surface. The most distinctive feature of the biopsies from patients with duodenal ulceration is the presence of bacteria (Fig. 3) on the surface of the gastric-type epithelial cells (Table 4). Bacteria are found on the surface of eight out of the 11 patients having duodenal ulceration (Table 4). The incidence of bacteria on the surface of the prepyloric mucosa in this limited sample of patients with duodenal ulceration is $73 \%$ (in one patient the epithelial surface could not be examined because of the complete covering of mucus). The endoscopic biopsies are small (ca 2-3 mm diameter) so that the epithelial surface examined is greatly limited. The incidence of bacteria on the epithelial surface of the prepyloric area might therefore be greater than $73 \%$ but this cannot be substantiated from this study. The bacteria are not uniformly distributed over the surface of the epithelial cells (Figs. 3, 5): some areas lack bacteria, other areas have small numbers of bacteria, whereas in other areas the bacteria are present in large numbers (Fig. 4). The bacteria are most numerous among the microvilli in the 'gutters' 


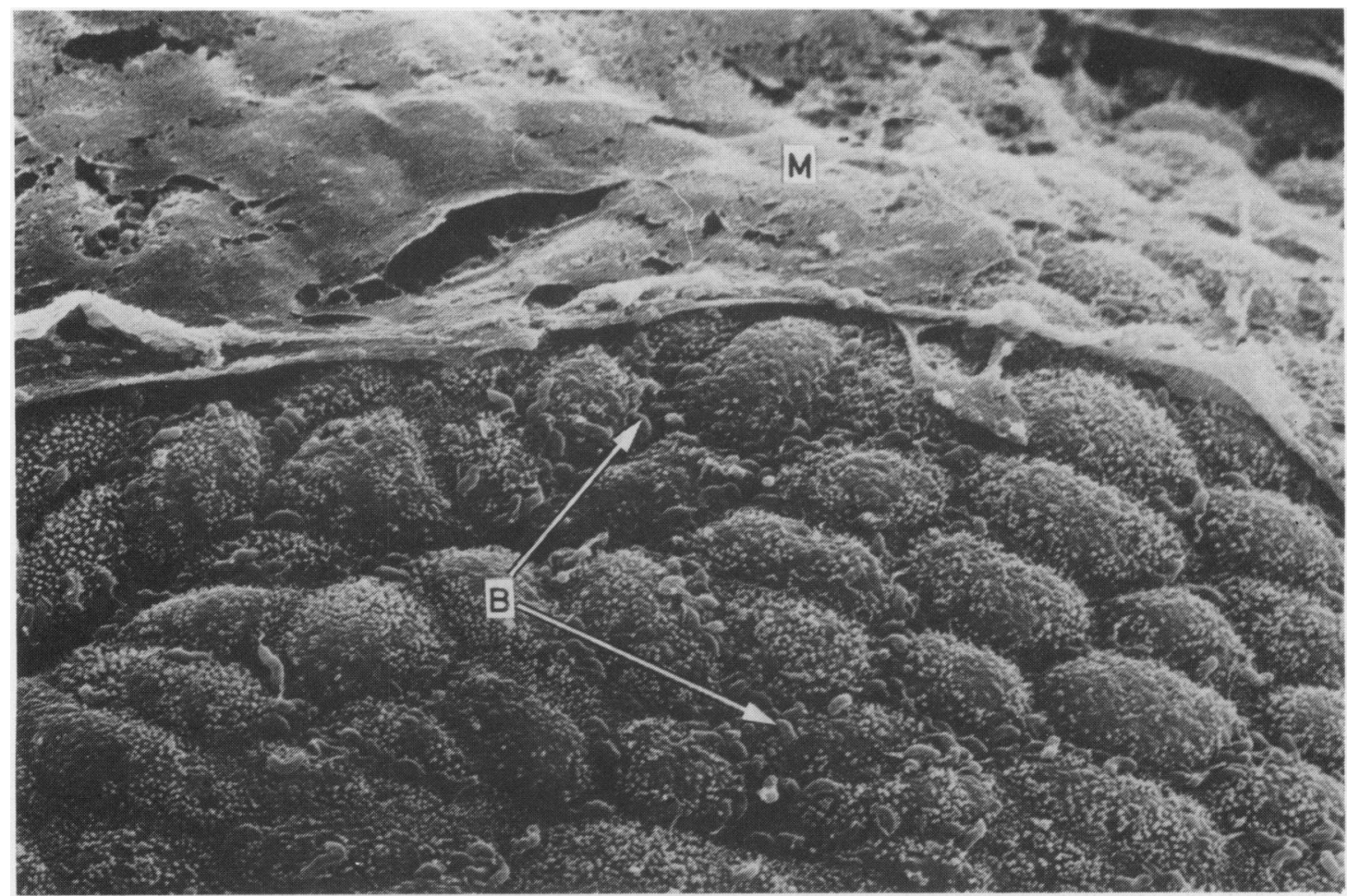

Fig. 3 Prepyloric mucosal surface of a patient with duodenal ulceration. The specimen shows gastric epithelial cells whose surface is covered over a large area with mucus $(M)$. Covering the gastric epithelial cells are numerous bacteria $(B)$ which are absent from the visible surface of the mucus $(\times 2800$ original magnification $)$.

Table 4 Histology and scanning electron microscope findings in biopsies from the duodenal ulcer patients and the patient with only prepyloric gastritis

\begin{tabular}{|c|c|c|}
\hline Patient number & Histology & Scanning electron microscope findings \\
\hline 14 & $\begin{array}{l}\text { Gastric metaplasia in duodenal cap. Severe acute gastritis } \\
\text { in prepyloric area }\end{array}$ & $\begin{array}{l}\text { Bacteria in duodenal cap and prepyloric biopsies (all } \\
\text { biopsies) }\end{array}$ \\
\hline 15 & $\begin{array}{l}\text { Normal in duodenal cap. Severe acute gastritis with areas } \\
\text { of intestinal metaplasia in prepyloric area }\end{array}$ & $\begin{array}{l}\text { No bacteria in duodenal cap. Bacteria in prepyloric } \\
\text { area ( } 5 \text { out of } 7 \text { biopsies) }\end{array}$ \\
\hline 16 & Gastric metaplasia in duodenal cap & Bacteria in duodenal cap ( 3 out of 4 biopsies) \\
\hline 17 & $\begin{array}{l}\text { Moderate acute gastritis with areas of intestinal metaplasia } \\
\text { in prepyloric area }\end{array}$ & Bacteria in prepyloric area ( 1 out of 3 biopsies) \\
\hline 18 & Severe acute gastritis in prepyloric area & Bacteria in prepyloric area ( 2 out of 2 biopsies) \\
\hline 19 & $\begin{array}{l}\text { Gastric metaplasia in duodenal cap. Moderate acute } \\
\text { gastritis in prepyloric area }\end{array}$ & $\begin{array}{l}\text { Bacteria in duodenal cap and prepyloric areas ( } 6 \text { out of } \\
6 \text { biopsies) }\end{array}$ \\
\hline 20 & Gastric metaplasia in duodenal cap & Whole of the epithelial surface covered with mucus \\
\hline 21 & $\begin{array}{l}\text { Gastric metaplasia in duodenal cap. Severe acute gastritis } \\
\text { with areas of intestinal metaplasia in prepyloric area }\end{array}$ & $\begin{array}{l}\text { Bacteria in duodenal cap and prepyloric areas ( } 7 \text { out of } \\
7 \text { biopsies) }\end{array}$ \\
\hline 22 & Severe acute gastritis in prepyloric area & Bacteria in prepyloric area ( 4 out of 4 biopsies) \\
\hline 23 & $\begin{array}{l}\text { Gastric metaplasia in duodenal cap. Moderate acute } \\
\text { gastritis with areas of intestinal metaplasia in prepyloric } \\
\text { area }\end{array}$ & $\begin{array}{l}\text { No bacteria. Extensive mucus covering the epithelial } \\
\text { surface limiting the view of the cell surface }\end{array}$ \\
\hline 24 & $\begin{array}{l}\text { Gastric metaplasia in duodenal cap. Moderate acute } \\
\text { gastritis in prepyloric area }\end{array}$ & No bacteria in duodenal eap or prepyloric area \\
\hline 25 & Severe acute gastritis in prepyloric area & Bacteria in prepyloric area ( 3 out of 4 biopsies) \\
\hline
\end{tabular}




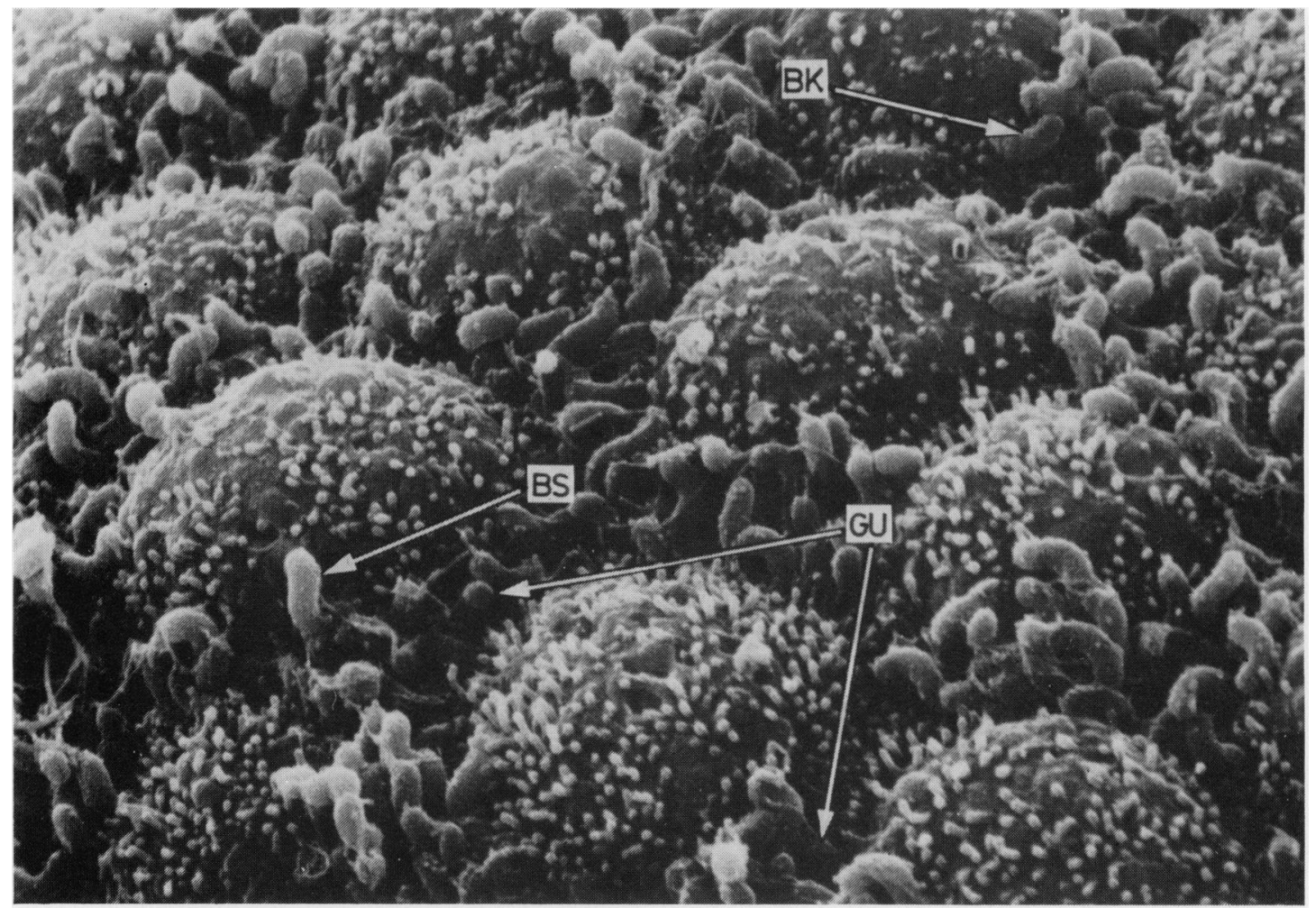

Fig. 4 Detailed study of the gastric epithelial cell surface from a prepyloric biopsy from a patient with duodenal ulceration. The dome-shaped surface of the cells are apparent. The microvilli are less numerous than in the normal biopsies. Numerous bacteria (BS and $B K$ ) are present and located in the gutters $(G U)$ near the edges of the cells' surface. The bacteria are either $S$-shaped $(B S)$ or 'kidney' shaped $(B K)(\times 7250$ original magnification $)$.

at the edge of the luminal surface of the cells (Fig. 4). Where the bacteria are near the edge of a mucus plaque (Fig. 3), they are found in the depths between cells and give the impression of being numerous beneath the mucus edge.

The junction between the gastric type epithelial cells and the intestinal type epithelial cells is occasionally seen (Fig. 5). The intestinal type epithelium presents a more uniformed surface with the area covered by microvilli which are packed together more densely than on the gastric type epithelial cells. Although possible to distinguish the edges of individual intestinal type epithelial cells this is more difficult than in the gastric type cell area because of the uniformity of the microvillous surface. This uniformity is interrupted by the apical surface of goblet cells (Fig. 5). This produces the only major irregularity of the intestinal type area. The other significant difference between the two epithelial areas is the absence of bacteria on the intestinal type area.
The bacteria are of two different shapes (Fig. 4). The majority of bacteria $(86 \cdot 8-95 \cdot 2 \%)$ are bacilli which are curved in their long axis (Fig. 4). These bacilli are ca $1.8 \mu \mathrm{m}$ in length and $0.75 \mu \mathrm{m}$ in diameter. They have at least one filum at one end. The other type of bacterium is also bacillus but is longer being ca $2.0 \mu \mathrm{m}$ in length. The other distinctive feature of these longer bacilli is their S-shaped configuration (Fig. 4). This type of bacillum also has a filum at one end. Whether the two morphological types of bacteria are related or represent distinct entities cannot be determined from this study but no intermediate forms have been seen suggesting two separate bacterial entities.

\section{Discussion}

The presence of bacteria on the epithelial surface adjacent to the ulcer or from the prepyloric area in patients with duodenal ulceration confirms the previous evidence for the existence of bacteria 


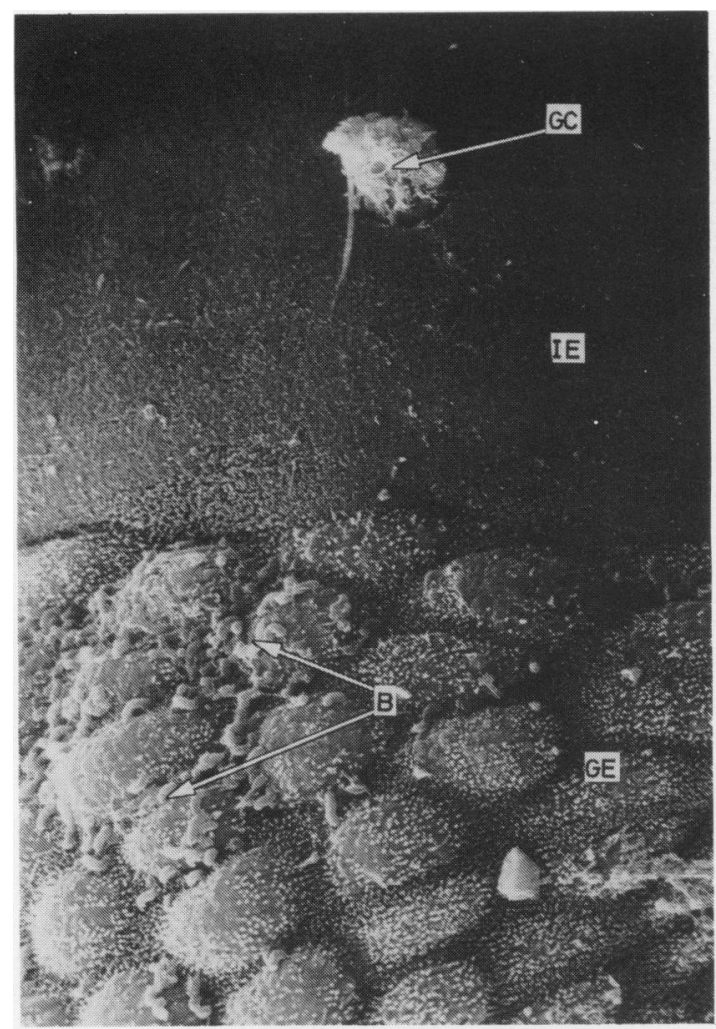

Fig. 5 Junction between an area of gastric-type epithelium $(G E)$ and intestinal-type epithelium (IE). Bacteria (B) are only related to the gastric-type epithelium. The uniformity of the intestinal-type epithelium is broken by an erupting goblet cell $(G C)(\times 3100$ original magnification $)$.

related to the gastric mucosa in a significant number of patients with peptic ulceration. ${ }^{56}$ The distribution of these bacteria confirms the previous conclusion that these bacteria are not contaminants from the endoscopy and biopsy. They are absent from the control patients who have a normal stomach and duodenum. When present the bacteria are only related to the gastric type epithelial surface. They are not uniformly distributed over the mucosal surface of an individual biopsy and are absent from the small intestinal type areas. Moreover, the bacteria are adherent to the epithelial surface adherence is a criteria for the pathogenecity of certain bacteria. Although the control patients in this study were not matched as far as age and sex are concerned with the duodenal ulcer patients, it has been previously shown that age and sex did not correlate with the presence of bacteria. ${ }^{56}$

There is considerable knowledge of the ultra- structural appearances of the gastroduodenal mucosa in duodenal ulceration. ${ }^{5}$ The present study corroborates the previous data with respect to the epithelial surface characteristics. The small intestinal type mucosal surface differs markedly from the gastric type mucosal surface not only in their morphological appearance but also in the relationship to bacteria. These bacteria have the same structural characteristics as those observed in the previous studies, namely, bacilli bearing a filum at one pole and are intimately adherent to the surface of gastric type epithelial cells. It is obvious, however, from this present study that the bacteria are of two morphological types - a rod-like bacillus which is curved in its long axis and an S-shaped bacillus. This was not obvious from the previous studies and its significance has still to be discerned.

The identification of these bacteria has yet to be resolved. Earlier studies have suggested that they are Pseudomonas seruginosa ${ }^{6}$ but this organism is known to be a contaminant of endocopic equipment. Whether the two morphological types identified in the present study represent two forms of the same bacterium or two bacterial types remains to be substantiated.

The finding of these bacteria in peptic ulceration, their distribution and the changes induced by the healing of the ulceration ${ }^{6}$ gives rise to the possibility that these organisms are implicated in the aetiology of peptic ulceration.

Lactobacilli and streptococci are related to the epithelial cell surface of the para oesophagea (nonsecretory region) of the normal pig's stomach. ${ }^{8}$ The adhesion of these lactobacilli may contribute to pig's mucosal defence against pathogenic organisms. ${ }^{9}$ The bacteria noted in the present study are considered not to be of benefit to the ulcer patients because of their absence from the normal human stomach, their localisation to areas of acute gastritis and their reduction in quantity with healing of the ulcer.

\section{Addendum}

Since this work was submitted, the findings have been confirmed by Phillips et al ${ }^{10}$ but it would be wrong to come to any conclusions as to the nature of the organisms from a scanning electron microscopic study.

The expert technical assistance of $\mathrm{Mr} \mathrm{C}$ Inman is gratefully acknowledged. 


\section{References}

1 Bottcher. Dopater med $Z$ 1874; 5: 148. (Cited by Barber and Franklin 1946.)

2 Rosenow EC, Sandford AH. The bacteriology of ulcer of the stomach and duodenum in man. $J$ Infect Dis 1915; 17: 210-26.

3 Appelmans R, Vassiliadis P. Étude sur la flore microbienne des ulcers gastro-duodeneaux et des cancers gastriques. Rev Belge Sci Med 1932; 4: 198-203.

4 Seley GP, Colp R. The bacteriology of peptic ulcers and gastric malignancies: possible bearing on complications following gastric surgery. Surgery 1941; 10: 369-80.

5 Steer HW. Ultrastructure of cell migration through the gastric epithelium and its relationship to bacteria. $J$
Clin Pathol 1975; 28: 639-46.

6 Steer HW, Colin-Jones DG. Mucosal changes in gastric ulceration and their response to carbenoxolone sodium. Gut 1975; 16: 590-7.

7 Richardson KC, Jarret L, Finke EH. Embedding in epoxy resins for ultrathin sectioning in electron microscopy. Stain Technol 1960; 35: 313-23.

8 Fuller R, Barrow PA, Brooker BE. Bacteria associated with the gastric epithelium of neonatal pigs. Appl Environ Microbiol 1978; 35: 582-91.

9 Barrow PA, Brooker BE, Fuller R, Newport MJ. The attachment of bacteria to the gastric epithelium of the pig and its importance in the microecology of the intestine. J Appl Bacteriol 1980; 48: 147-54.

10 Phillips AD, Hine KR, Holmes GKT, Woodings DF. Gastric spiral bacteria [Letter]. Lancet 1984; 1: 100-1. 